\title{
CLEARING THE AIR: AN EXAMINATION OF INTERNATIONAL LAW ON THE PROTECTION OF THE OZONE LAYER
}

\section{TIMOTHY C. FARIES ${ }^{*}$}

The author, after examining the existing international law on ozone layer protection, explains the current scientific knowledge about the causes and effects of ozone layer depletion. The author then embarks on a discussion of the sources of international environmental law on ozone depletion, and draws analogies to the broader area of international law dealing with state responsibility for transnational air pollution emanating from within its territory. Mr. Faries then proceeds to provide a brief history of the events leading up to the signing of the Montreal Protocol, followed by an analysis of the subtleties of the Protocol, and suggestions for reform.
Après avoir examiné les lois de droit intemational assurant actuellement la protection de la couche d'ozone, l'auteur explique quelles sont les connaissances scientifiques actuelles sur les causes et effets de la raréfaction de la couche d'ozone. Il engage une discussion sur les sources des lois internationales abordant le sujet et établit des analogies avec le domaine plus vaste du droit intemational traitant de la responsabilité de l'Etat en matière de pollution atmosphérique transnationale é manant à l'intérieur de son territoire. M. Faries passe ensuite à un bref historique des événements qui ont conduit a la ratification du Protocole de Montreal. Il foumit une analyse des subtilités qu'il contient et offre des suggestions de réforme.

\section{TABLE OF CONTENTS}

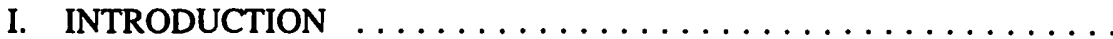

II. DEFINING THE PROBLEM: OZONE AND

CHLOROFLUOROCARBONS, WHAT ARE THEY AND WHY IS

EVERYONE TALKING ABOUT THEM? ..............

III. PRELUDE TO THE PROTOCOL: AN OVERVIEW OF

INTERNATIONAL ENVIRONMENTAL LAW DEVELOPMENT

LEADING TO THE MONTREAL PROTOCOL . . . . . . . . .

A. CUSTOMARY INTERNATIONAL LAW

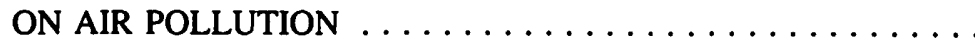

1. The Trail Smelter Arbitration . . . . . . . . . . . . . . . 824

2. The Corfu Channel Case ................... 825

3. The Stockholm Declaration on the Human Environment . . . . 826

4. Assessment .......................... 827

B. BETWEEN A DECLARATION AND A

PROTOCOL: THE ARDUOUS JOURNEY

FROM STOCKHOLM TO MONTREAL . ...........

1. The United Nations Enviroment Programme (UNEP) . . . . . . .

2. The Vienna Convention for the

Protection of the Ozone Layer $\ldots \ldots \ldots \ldots \ldots \ldots \ldots$

IV. THE MONTREAL PROTOCOL ................ 830

A. AN OVERVIEW OF THE MONTREAL PROTOCOL . . . . . 830

Mr. Faries is currently articling with the Edmonton law firm of Corbett and Company. This paper was a prize winning essay in the William Morrow Essay Contest. 
1. Control Measures ...................... 831

2. Trade Restrictions with Non-Parties ............. 833

3. Developing Countries .................. 834

4. Other Provisions .................... 835

B. CRITICAL ANALYSIS OF THE MONTREAL PROTOCOL . . ... 835

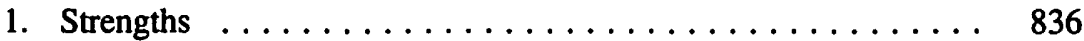

2. Weaknesses ....................... 836

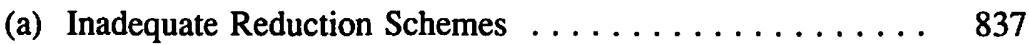

(b) Unnecessarily Broad Concessions $\ldots \ldots \ldots \ldots \ldots \ldots .838$

V. PROPOSALS FOR CHANGE $\ldots \ldots \ldots \ldots \ldots \ldots \ldots \ldots \ldots \ldots, 841$

VI. CONCLUSION .......................... 843

\section{INTRODUCTION}

Exhaustion of the stratospheric ozone layer by the introduction of man-made pollutants will have alarming environmental consequences if the depletion is not effectively checked.' This timely environmental issue, while of global concern, is especially pressing on Canada. ${ }^{2}$ Significant depletion of the ozone layer in the Canadian Arctic was first noted by scientists in 1986, and recent reports indicate that a substantial loss has been suffered over urban areas as well. ${ }^{3}$

In recent years, as a more accurate understanding of the exact nature and extent of ozone layer depletion has been acquired, the need for immediate, effective measures to prevent further dissipation of stratospheric ozone has been recognized. Steps have been taken by international organizations to develop multi-lateral agreements to curb the use by individual states of ozone-damaging products. In particular, the United Nations Environment Programme (UNEP) has been instrumental in coordinating the negotiations for, and drafting of, the 1987 Montreal Protocol on Substances that Deplete the Ozone Layer, ${ }^{4}$ the first major international agreement setting out specific direction on ozone layer protection.

This paper will undertake to conduct an examination of existing international law on the protection of the ozone layer. Beginning with a brief investigation of current scientific knowledge about the causes and effects of ozone layer depletion, ${ }^{5}$ the paper will go on to review the sources of international environmental law on the subject. This will include

1. Environmental consequences include detrimental effects on terrestrial and aquatic ecosystems, a weakening of the human immune system, and an increase in the incidence of melanoma and nonmelanoma cancers with a concordant increase in the mortality rate of these diseases. See infra, notes 34-37 and accompanying text.

2. See infra, note 31 .

3. "Ozone loss over Toronto confirmed" Edmonton Journal (26 October 1989) B-14.

4. Montreal Protocol on Substances that Deplete the Ozone Layer, opened for signature September 16 , 1987, C.N. 239 (1987), reprinted in 26 I.L.M. 1541(1987) [hereinafter, Montreal Protocol or Protocol] ratified by Canada on June 30, 1988). The Montreal Protocol went into force as of January 1,1989, since the requisite number of CFC producing nations had ratified it (see especially Article 16 of the Protocol at $1559-60$ of the reprint).

5. See infra, notes 10-37 and accompanying text. 
an overview of customary sources of international law on air pollution and state responsibility, ${ }^{6}$ which provide the framework for more detailed law on the ozone layer. Then, a brief history of the negotiations and steps which led specifically to the signing of the Montreal Protocol will be outlined ${ }^{7}$ to set the stage for a thorough and critical analysis of the Protocol itself. ${ }^{8}$ Finally, proposals for amendments to the Protocol will be made, with a view to transcending the shortfalls inherent in it, and establishing an effective multi-lateral agreement that will obviate the ozone layer problem. ${ }^{9}$

\section{DEFINING THE PROBLEM: OZONE AND CHLOROFLUOROCARBONS, WHAT ARE THEY AND WHY IS EVERYONE TALKING ABOUT THEM?}

High-level or stratospheric ozone is the only gas in the earth's atmosphere that prevents harmful ultraviolet solar radiation from reaching the earth's surface. ${ }^{10}$ By a curious twist of nature, ozone, a molecular compound consisting of three oxygen atoms, $\left(\mathrm{O}_{3}\right)$, our all-important shield from UV-B radiation, is itself formed by short-wave solar radiation interacting with normal oxygen molecules $(\mathrm{O} 2)$ in the atmosphere. " Ultraviolet radiation striking molecular oxygen has the effect of separating the molecular bond between the two oxygen atoms. These oxygen atoms $(O)$ then recombine individually with other oxygen molecules $\left(\mathrm{O}_{2}\right)$ to create ozone $\left(\mathrm{O}_{3}\right)^{12}$ This on-going chemical process of creation has subsisted for as long as there has been oxygen in the earth's atmosphere. On the earth's surface, the combination of diatomic oxygen $\left(\mathrm{O}_{2}\right)$ with stray oxygen atoms is an unhealthy pollutant, the by-product of automobile exhaust and other industrial excretions. ${ }^{13}$ While this low-level ozone contributes to poor air quality and smog, stratospheric ozone is an indispensable ingredient in the maintenance of the earth's fragile environmental health. The ozone layer, a sparsely filled ${ }^{14}$ but wide band of naturally produced 'smog' stretching six to thirty miles ${ }^{15}$ above the planet's surface, preserves life as we know it on the earth.

See infra, notes 38-55 and accompanying text.

See infra, notes 56-72 and accompanying text.

See infra, notes 73-150 and accompanying text.

See infra, notes 151-164 and accompanying text.

See Odgen, D.H., "The Montreal Protocol: Confronting the Threat to the Earth's Ozone Layer" (1988) 63 Washington Law Review 997, n. 2. Ozone also absorbs infrared radiation and is a contributing factor to the maintenance of atmospheric temperature. Blegen, B., "International Cooperation in Protection of Atmospheric Ozone: The Montreal Protocol on Substances that Deplete the Ozone Layer" (1988) 16 Denver Journal of International Law and Policy, 413 at 414.

See also Cappretta, A.M., "The Future's So Bright I Gotta Wear Shades: Future Impacts of the Montreal Protocol on Substances that Deplete the Ozone Layer" (1988) 29 Virginia Joumal of International Law 211 at 216 . The shorter the wave-length, the more harmful the radiation.

See Nangle, O.E. "Stratospheric Ozone: United States Regulations of Chlorofluorocarbons", (1989) 16 Boston College Environmental Affairs Law Review 531 at 536.

Kindt, J.W., and Menefee, S.P., "The Vexing Problem of Ozone Depletion in International Environmental Law and Policy", (1989) 24 Texas International Law Joumal 261 at 263.

14. If all the stratospheric ozone layer was subjected to the equivalent of sea-level air pressure, it would be compressed into a thin band only three centimetres thick. See also Nangle, supra, note 12 at 535 . See Kindt and Menefee, supra, note 13 at 262. 
While the creation of individual ozone molecules is a perpetual process, so too the natural destruction of ozone molecules has always been a vital element in the maintenance of ozone levels in the earth's stratosphere. ${ }^{16}$ Ozone is an extremely unstable molecular compound, and is broken up by several naturally occurring molecular compounds present in the atmosphere. ${ }^{17}$ Thus, the preservation of the ozone layer in the past has been through this continual process of creation and destruction occurring naturally in the stratosphere, allowing ozone levels to remain constant, and providing an effective buffer from solar radiation. ${ }^{18}$

In this century, however, this dynamic balance in the ozone layer has been upset by the introduction of man-made ozone-destroying chemical compounds into the stratosphere. ${ }^{19}$ Of these compounds, chlorofluorocarbons (CFCs) have been the most detrimental to stratospheric ozone due to their wide-spread use and their individual potential for destruction. ${ }^{20}$ First manufactured by General Motors in 1928, CFCs gained popularity in the post-World War II era because of their versatility. ${ }^{21}$ CFCs are non-toxic, non-flammable, non-corrosive, odourless, extremely stable and available for use in a wide range of modern industries. ${ }^{22}$ The United States Environmental Protection Agency estimated that world-wide industrial use of CFCs amounted to 2.5 billion pounds in 1986. ${ }^{23}$ Unfortunately, these very qualities which make CFCs so beneficial for industry make them detrimental to the environment.

Although the exact reason why CFCs deplete the ozone layer has not been conclusively proved, there is wide-spread acceptance in the scientific community of the "chemical ozone depletion theory" propagated by Drs. F.S. Rowland and M.J. Molina of the University of California at Irvine in the early 1970's, when concerns about CFCs and

16. Ozone is destroyed naturally when the ozone molecule recombines with other oxide compounds (such as nitrogen oxide) to form two molecules of diatomic oxygen $\left(\mathrm{O}_{2}\right)$. See also Rowland, F.S., "A Threat to the Earth's Protective Shield", (1986) 12 E.P.A.J. (No. 10) 4.

17. The main tropospheric gases that affect ozone are: i) methane $\left(\mathrm{CH}_{4}\right)$; ii) nitrous oxide $\left(\mathrm{N}_{2} \mathrm{O}\right)$; iii) nitrogen oxide (NO); iv) carbon monoxide (CO); and v) carbon dioxide $\left(\mathrm{CO}_{2}\right)$. See also $\mathrm{Kindt}$ and Menefee, supra, note 13 at 263. See Rowland, supra, note 16 at 14.

19. Mainly chlorofluorocarbons (CFCs) and halons (used in fire extinguishers). See Cappretta, supra, note 11 at 216.

20. It has been estimated that a single chlorine atom released from one CFC molecule destroys 100,000 ozone molecules. See also Lemonick, M.D., "The Heat is On: Chemical Wastes Spewed into the Air Threaten the Earth's Climate", Time, 19 October 198758 at 62 . CFCs are a subcategory of halocarbons, which are compounds of carbon and one of the halogens (fluorine, chlorine, bromine and iodine). See also Nangle, supra, note 12 at 533.

21. Lemonick, supra, note 20 at 61 .

22. CFCs are used in a variety of areas including: i) as coolants in refrigerators and air conditioners; ii) as propellants in aerosol spray cans (although this use has been banned in Canada since 1980); iii) as solvents; iv) as components in the manufacture of plastic foam; $v$ ) as agents in medical equipment sterilization; vi) in computer chips. Alternatives to CFC use as refrigerants has existed since 1981. See Kindt and Menefee, supra, note 13 at 264-265. Also see Tripp, J.T.B., "The UNEP Montreal Protocol: Industrialized and Developing Countries Share the Responsibility for Protecting the Stratosphere Ozone Layer", 20 New York University Journal of International Law and Politics 7334 at notes 9-10 and accompanying text. 
ozone layer depletion were first voiced. ${ }^{24}$ CFCs are gases at room temperature and are released into the atmosphere when used..$^{25}$ Due to their stability as an inert

gas, they do not break down in the troposphere, the dynamic lower layer of the earth's atmosphere where the atmosphere fluctuations we call 'weather' occur. ${ }^{26}$ Rather, they remain intact and eventually ascend to the more stable stratosphere. ${ }^{27}$ Once in the stratosphere, CFCs are subjected to solar radiation, which has the effect of releasing a chlorine atom from the compound. ${ }^{28}$ The chlorine atom then attacks an ozone molecule causing a two-part chemical reaction which destroys the ozone molecule and frees the chlorine atom to repeat the process. ${ }^{29}$ When one considers the potential for destruction inherent in each chlorine atom released from a CFC molecule, and the amount of CFC's being released into the atmosphere, the future of the ozone layer looks very ominous. ${ }^{30}$

As it is, significant depletion of the ozone layer has been noticed in parts of the world already. ${ }^{31}$ Most dramatic is the Antarctic seasonal 'hole' in the ozone layer, where ozone levels are diminished by as much as $50 \%$ in the spring. ${ }^{32}$ The obvious result of a decrease in the levels of stratospheric ozone is a consequent increase in the penetration of damaging ultraviolet rays from the sun. ${ }^{33}$ This increase would have disastrous results

See Rowland, F.S. and Molina, M.J., "Stratospheric Sink for Chlorofluoromethanes: Chlorine Atom Catalyzed Destruction of Ozone", (1974) 249 Nature 810. See Nangle, supra, note 12 at 535.

26. Ibid. at 534. The cause of the dynamism of the troposphere is the presence of cool, heavy air resting above warmer, lighter surface air. At a certain height in earth's atmosphere, called the 'tropopause', the air reaches its coldest temperature, and begins to heat up again with ascending altitude. Thus the stratosphere, which contains the ozone layers, has the cooler, heavier air on the bottom with the warmer, lighter air above, resulting in atmospheric stability with very little weather activity.

This process may take years. Scientists estimate that as much as $90 \%$ of CFCs released are still in the troposphere and have yet to work their destruction on the ozone layer. See Kindt and Menefee, supra, note 13 at 267.

In the case of halons, bromine is the destroying agent. See Nangle, supra, note 12 at 533.

The two-part chemical reaction is as follows: Step One: The chlorine atom reacts with an ozone molecule producing chlorine oxide and diatomic oxygen $\left(\mathrm{CI}+\mathrm{O}_{3}=\mathrm{CI}+\mathrm{O}_{2}\right)$; Step Two: The chlorine oxide molecule reacts with a stray oxygen atom to form diatomic oxygen and chlorine (CIO $\left.+\mathrm{O}=\mathrm{O}_{2}+\mathrm{CI}\right)$. See also Kindt and Menefee, supra, note 13 at 264.

CFCs are very stable compounds and have a life expectancy of between 75 and 185 years. Therefore, even if CFC production were stopped immediately it would take over 100 years to "clear the air" of the compounds. See also Ogden, supra, note 10 at 999-1000.

Scientists theorize that ozone depletion is greater in regions closer to the poles (latitudes above $40^{\circ}$ North and below $40^{\circ}$ South) than tropical zones. This is particular importance for Canada, which, it is believed, suffered a $3 \%$ decrease in ozone levels since 1969. See also Odgen, supra, note 10 at 998. Due to the dynamic nature of ozone's creation and destruction, it is difficult to determine with any accuracy the past, present, or future levels of ozone in the stratosphere, and consequently, the extent of ozone level depletion is a subject of much debate. Recent satellite mapping discounts the above figure as conservative and suggests a $1 \%$ depletion per year in ozone levels between 1979 and 1986. See Bowman, "Global Trends in Total Ozone", (1988) 239 Science 48 at 49. 3.

33. For every $1 \%$ decrease in ozone levels, there is a $2 \%$ increase in the amount of harmful UV-B rays reaching the earth's surface. See also Shabecoff, P., "Study Shows Significant Decline in Ozone Layer", New York Times (16 March 1988) A 25. 
on aquatic and agrarian ecosystems, ${ }^{34}$ as well as human health. ${ }^{35}$ It is also believed that the existence of CFCs in the atmosphere traps infrared radiation reflected from the Earth, contributing to the "greenhouse effect", a global warming trend which is anticipated to result in a score of environmental woes. ${ }^{36}$ Perhaps the worst part of the entire situation is that the dire consequences of CFC infiltration into the earth's atmosphere will, for the most part, be visited upon people yet unborn, a macabre legacy indeed of twentieth century industrial excess. ${ }^{37}$

\section{PRELUDE TO THE PROTOCOL: AN OVERVIEW OF INTERNATIONAL ENVIRONMENTAL LAW DEVELOPMENT LEADING TO THE MONTREAL PROTOCOL}

The problem of ozone layer depletion is unique among environmental concerns. Due to the stability and long life of CFCs, the compound, once released into the troposphere, becomes subject only to the vagaries of the wind, and knows no national borders. CFCs released from an automobile air conditioner in Edmonton today may well be destroying ozone molecules over Madagascar thirty years from now. It is truly a global dilemma. The termination of CFC use in Canada would not mean the portion of the ozone layer above Canada would be free from further depletion. All CFC production everywhere must be halted to secure the integrity of the ozone layer for the future. While other more localized environmental concerns can be said to affect the entire world indirectly, ozone layer depletion directly affects everyone. This section explores the early sources of public international law on ozone depletion, scrutinizing both the customary sources which developed the international legal concept of state responsibility for transboundary air pollution, and the specific multi-lateral agreements addressing the broad issue of international environmental law. It then gives an overview of the steps taken by various international organizations to coordinate and draft a document specifically addressing measures by which ozone layer depletion could be arrested, which led ultimately to the signing of the Montreal Protocol.

\section{A. CUSTOMARY INTERNATIONAL LAW ON AIR POLLUTION}

When considering the development of international treaties, such as the Montreal Protocol, it is helpful to first review the customary sources of public international law

34. Harmful UV-B rays will cause mutations in plant and animal life, causing damage to crops and agrarian ecosystems. UV-B rays can penetrate through 20 feet of clear water and will destroy vast amounts of the microscopic sea life that forms the base of many aquatic food chains. Depletion of stratospheric ozone will result in higher levels of tropospheric ozone ('smog'), exacerbating the already polluted air conditions. See also Nangle, supra, note 12 at 537-539.

35. Additional short wave radiation will cause an increase in the incidence of non-melanoma cancers and skin cancer, escalating the mortality rate for these diseases. Solar radiation also has a detrimental effect on human immune systems; it causes an increase in cataracts and could destroy DNA, ibid. Actually, the destruction of the ozone layer will only warm the earth until depletion becomes extensive, at which time temperatures will cool significantly. See also Kindt and Menefee, supra, note 13 at 267.

37. Theoretically, complete dissipation of the ozone layer could result in the extinction of life on earth, ibid. 
which provided the basis from which those later developments proceeded. While public international law on ozone layer depletion is a new and emerging field, its sources can be traced to earlier pronouncements on the control of transboundary pollution. These general principles enunciated in earlier case decisions and declarations portray the early development of customary international law on state responsibility and air pollution. This provides the framework for a detailed analysis of the recently signed multi-lateral agreements which resolve, on a global scale, to arrest ozone layer depletion.

\section{The Trail Smelter Arbitration ${ }^{38}$}

Customary international law on environmental protection is of recent vintage; indeed, the entire body of law in this area is a product of the twentieth century, when the detrimental effects effects of industrialization began to be felt worldwide. The Trail Smelter Arbitration represents one of the first exhaustive pronouncements on a state's responsibility to control and prevent industrial excess from crossing transnational boundaries. $^{39}$ The case initially involved a dispute between private citizens in Stevens County, Washington and the Consolidated Mining and Smelting Company of Canada (hereinafter Consolidated), owners and operators of a smelter located at Trail, British Columbia, eleven miles from the Canada-U.S. border. Consolidated had acquired the smelter in 1906, and as a by-product of the smelting process, released harmful sulphur dioxide into the air, which wafted across the border causing damage to nearby farms and homes. In 1925, Consolidated received its first formal complaint from a disgruntled Washington farmer who claimed the sulphur dioxide emissions were damaging his livestock. In response to this, Consolidated launched an investigation into the emission problem, concluded damage was being done, and proceeded to negotiate settlements with complainants. This was not enough for the residents of Stevens County. Although dissuaded from launching a private suit in tort for damages against Consolidated because of an 1893 decision of the House of Lords ${ }^{40}$ which laid down the rule that a court did not have authority to hear suits based on damage to land located outside its jurisdiction, the Stevens County residents nonetheless took their grievances to the American government. The American government in turn, took up the claim with its Canadian counterpart, and requested the dispute be settled by an international joint commission. The commission assessed damages up to January 1,1932 at $\$ 350,000$. Unfortunately for the residents of Stevens County, emissions of sulphur dioxide continued beyond 1932. Because of this the two countries signed a convention in 1935 establishing an arbitral tribunal to decide the issue.

This case was a landmark decision in that it introduced a concept of state responsibility in the area of transboundary pollution that was far more comprehensive than the general international law principles. Previously, only states were recognized as subjects of

Trail Smelter Arbitration (U.S. v. Canada) (1941), 3 R.I.A.A. 1905.

See generally, Hoffman, K.B., "State Responsibility in International Law and Transboundary Pollution Injuries", (1976) 25 International and Comparative Law Review Quarterly 509.

British South African Company v. Companhia de Moçambique, [1983] A.C. 602. 
international law, ${ }^{41}$ yet this case involved private dispute between individuals and an independent corporation. The tribunal held the matter to be rightly within the scope of international law as the Canadian state was deemed to be "responsible in international law for the conduct of the Trail Smelter."42 Thus, the foundational precept of public international law on transboundary air pollution was formulated: ${ }^{43}$

\begin{abstract}
No State has the right to use or permit use of its territory in such a manner as to cause injury by fumes in or to the territory of another, or the properties or persons therein, when the case is of serious consequences and the injury is established by clear and convincing evidence.
\end{abstract}

With this judgment, the development of public international law on transboundary pollution had begun.

\title{
2. The Corfu Channel Case ${ }^{44}$
}

Although not dealing directly with environmental issues, this 1949 decision of the International Court of Justice (ICJ) made an important statement on state responsibility that has been imputed to international law on the environment. The case concerned a damage claim by the United Kingdom for losses suffered by two British warships from mines laid in the Corfu Channel off the coast of Albania. The ICJ found as a matter of fact, based on indirect evidence, that the Albanian state knew or ought to have known of the mine laying operation in her territorial waters. This knowledge was sufficient in the minds of the ICJ justices to impose liability on Albania for the injury suffered by Britain as a result of those mines. The question of whether or not the Albanian state was an active participant in the mine laying was unimportant because knowledge of the existence of a minefield in its territorial waters was sufficient to make the Albanian state responsible. It is significant to note that, in coming to the conclusion that Albania was responsible, the ICJ did not refer to any specific treaty or international convention. Their judgement was based on the "general and well-recognized principle"45 that it was "every State's obligation not to allow knowingly its territory to be used contrary to the rights of other states", ${ }^{46}$ and Albania had a duty to inform the British warships of their imminent danger. Applying this customary tenet of international law to the subject of ozone layer depletion, one could credibly argue that all states have a right to protection from unhealthy solar radiation. Any State which knowingly allows the use of ozone destroying chemicals is in direct violation of an established principle of international law.

\section{The Stockholm Declaration on the Human Environment ${ }^{47}$}

41.

It is clear that other entities, such as international organizations, have limited status under intemational law. These organizations could be included as proper subjects of international law. For the purposes of this paper, however, it is unnecessary to deal with the distinction between states and international organizations as subjects of international law.

42. Trail Smelter Arbitration, supra, note 38 at 1965.

43. Ibid. at 1980.

44. Corfu Channel Case (Albania v. U.K.), [1949] I.C.J. 4.

45. Ibid. at 22.

46. Ibid.

47. Stockholm Declaration on the Human Environment, U.N. Doc. A/CONF 48/14 (1972), reprinted in 11 I.L.M. 1416 [hereinafter Stockholm Declaration]. 
The Trail Smelter and Corfu Channel cases are most significant as setting foundational principles of customary international law applicable to environmental issues. For 23 years following the Corfu Channel decision, these two pronouncements on state responsibility remained the central, and somewhat isolated, statements on international environmental law. ${ }^{48}$ The two decades which followed Corfu Channel saw the development of increasing public concern over environmental issues, particularly issues dealing with transboundary pollution. ${ }^{49}$ In 1968 , Sweden placed the topic of preservation of the human environment before the United Nations. ${ }^{\text {so }}$ This culminated in the United Nations Conference on the Human Environment, held at Stockholm, Sweden in 1972 which produced the Stockholm Declaration. ${ }^{51}$

The Stockholm Declaration is significant because it represents the first multi-lateral agreement asserting a state's responsibility for transboundary pollution, and embodies the customary principles of international environmental law explicitly enunciated in the Trail Smelter and Corfu Channel decisions. Apart from this however, its purpose was merely to make recommendations for further global action, and to state the guiding principles of environmental law, such as "the discharge of toxic substances...in such quantities or concentrations as to exceed the capacity of the environment to render them harmless, must be halted in order to ensure that serious or irreversible damage is not inflicted on our ecosystems. The just struggle of the peoples of all countries against pollution should be supported." 52 Such principles tend to be vague and ambiguous, and other than acting as an exhortation towards international cooperation on the development of more detailed agreements dealing with the protection of specific environmental matters, ${ }^{53}$ have limited practical use. Important to this analysis is Principle 21 which enunciates:

States have...the sovereign right to exploit their own resources...and the responsibility to ensure that activities within their jurisdiction and control do not cause damage to the environment of other States or of areas beyond the limits of national jurisdiction. ${ }^{54}$

This principle was not considered to be legally binding on states in and of itself, ${ }^{55}$ but it could be argued that, as an embodiment of the customary international law expressed in Trail Smelter, it does have some authority.

\section{Assessment}

See generally Bankes, N.D., and Saunders, J.D., "Acid Rain: Multi-lateral \& Bilateral Approaches to Transboundary Pollution under International Law", (1984) 33 University of New Brunswick Law Journal 155 at 159-61. See also the Lake Lanoux Arbitration (Spain v. France) (1957), 12 R.I.A.A. 281 , which outlined the responsibility of states to consult and negotiate with other states when they propose to engage in activities that pose potential danger to common environmental resources. Ibid. at 155.

U.N. Doc. E/4466/Add. 1 (1968); U.N. ECOSOC Res. 1346, U.N. ECOSOC Supp. 1, at 8, U.N. Doc.E/4561 (1968); G.A. Res. 2398, 23 U.N. GAOR Supp. 18, at 2. U.N. Doc. A/7218 (1968).

See supra, note 47. The Stockholm Declaration contained 26 principles and over 100 recommendations on environmental preservation.

Ibid. Principle 6.

lbid. Principles 22 and 24.

Ibid. Principle 21.

See Bankes and Saunders, supra, note 48 at 162. 
The development of customary international law on state responsibility and transboundary pollution, as evidenced in the Trail Smelter and Corfu Channel decisions, and embodied in Principle 21 of the Stockholm Declaration, represents the underlying foundation upon which later, more specific, multilateral agreements on ozone layer depletion were based. However, these customary sources of international law, in themselves, would be inadequate for the purposes of international law controlling ozone layer depletion. Implicit in both the Trail Smelter and Corfu Channel pronouncements on state responsibility is the idea that liability can only be imposed where a causal connection is established between the state making the emissions and the injury suffered by another state. In the field of ozone layer depletion it would be impossible to establish with certainty that the release of CFCs into the atmosphere by State A directly caused the depletion of the ozone layer over State B. Furthermore, even if such a determination were possible, how would one go about quantifying damage, the full effect of which is not yet understood nor will be for over 100 years? A more direct and complete agreement is necessary to adequately deal with ozone layer depletion in full.

\section{B. BETWEEN A DECLARATION AND A PROTOCOL: THE ARDUOUS JOURNEY FROM STOCKHOLM TO MONTREAL}

After the 1972 United Nations Conference on the Human Environment, initial steps were taken to deal with ozone layer depletion. At about the same time, Drs. Rowland and Molina were issuing the first reports on ozone layer depletion, and fingering CFCs as the possible culprit. ${ }^{56}$ The recommendations were thus centered on instituting an international committee of experts charged with analyzing the problem in detail with a view to tendering a proposed set of solutions. Although protection of the ozone layer was uniformly agreed to be of utmost significance, due to the paucity of knowledge on the nature and extent of the problem, the path from Stockholm to Montreal was a difficult one indeed.

\section{The United Nations Environment Programme (UNEP)}

Perhaps the most significant result of the Stockholm Conference was the establishment of UNEP. UNEP was founded pursuant to a recommendation put forth in the Declaration. ${ }^{57}$ In 1976, UNEP identified ozone layer depletion as an area of environmental law that warranted priority treatment. ${ }^{58}$ Consequently, in the following year, UNEP arranged a meeting of experts to assess the impact of ozone layer depletion on the global environment. ${ }^{59}$ Unfortunately, the general uncertainty in the scientific community of the exact nature and effect of ozone layer depletion on the environment that

56. See Rowland and Molina, supra, note 24.

57. Stockholm Declaration, supra, note 47, Part III - Resolution on Intemational \& Financial Agreements, 1. Governing Council for Environmental Programs, reprinted in 11 I.L.M. at 1466. The Governing Council of UNEP is comprised of 54 members elected for a three year term.

s8. $\quad$ Comment, "The Problem of Ozone Depletion - Is there an International Legal Solution?" (1987) 12 North Carolina Journal of International Law and Commercial Regulation 433 at 448.

59. See Sand, "Protecting the Ozone Layer: The Vienna Convention is Adopted", (1985) 27 Environment 119 at 40. 
existed at the time had a prohibitive effect on negotiations for a multi-lateral international agreement on the regulation of ozone destroying compounds. ${ }^{60}$ Canada, which reacted with relative rapidity in banning the use of CFCs in aerosol spray cans in $1980,{ }^{61}$ was among a group of countries (including the United States and Scandinavian nations) that proposed immediate and drastic reductions in CFC use world-wide. Other nations, including members of the European Economic Community (EEC) pointed to scientific data which suggested ozone layer depletion was not nearly as drastic as some anticipated, ${ }^{62}$ or attributed the depletion to some other cause, ${ }^{63}$ and contended that the reduction of CFC use would do little to ameliorate the predicament. Scientific uncertainty in the area was utilized to its full extent by each country in promoting national interests, and consequently negotiations towards a multi-lateral agreement were sluggish. UNEP was faced with the further hurdle that, since international environmental law in general, and international law on ozone layer depletion especially, were relatively new phenomena in international law, there was precious little in the way of precedent to go about determining an international solution to the ozone layer problem.

In the face of scientific uncertainty and a dearth of international jurisprudence, UNEP formed the Ad Hoc Working Group of Legal and Technical Experts (Working Group) in May, $1981,{ }^{64}$ charging the group with the responsibility of drafting a framework convention for ozone layer protection. ${ }^{65}$ The Working Group's fifth draft convention was finally signed on March 22, 1985 by twenty-one delegates at the Vienna Conference of Plenipotentiaries on Protection of the Ozone Layer. ${ }^{66}$

\section{The Vienna Convention for the Protection of the Ozone Layer ${ }^{67}$}

See generally, Doolittle, D.M. "Understanding Ozone Depletion: The Meandering Road to the Montreal Protocol and Beyond", 16 Ecology Law Quarterly 407 at 408-412.

Canada's ban on the use of CFCs as propellants is aerosol spray, hair spray and deodorant spray cans is found in Regulations SOR 80/254 (Can. Gazette Vol. 114, Part II, at 1289 (April 3, 1980) and SOR 81/365 (Can. Gazette Vol 115, Part II, at 1410 (May 7, 1981). The 1981 amendment simply expands the application of the ban from under arm deodorant spray cans, to all deodorant spray cans. These regulations were made pursuant to the Environment Contaminants Act, R.S.C. 1985, c. E-12. The 1980 Regulation came into force May 1, 1980.

In 1979, the British Meteorological Office forwarded a theory that the increased destruction of ozone caused by CFCs was offset by increased ozone creation due to unnaturally high amounts of carbon dioxide, another by-product of pollution, being released into the atmosphere. The equilibrium of creation/destruction of ozone was maintained, and CFC use posed no threat to ozone layer depletion. See Allaby, "Environment", 1979 Britannica Book of the Year 356 at 362. Indeed, proponents of this theory went so far as to estimate an overall increase of $6 \%$ in stratospheric ozone levels since 1920. It was once thought that supersonic jets flying at high altitudes would cause ozone layer depletion. See Doolittle, supra, note 60 at 410 . Brunnée, J., Acid Rain and Ozone Level Depletion: International Law and Regulation, (1988) at 227. Sand, supra, note 59 at 41: "A Framework convention is designed to be supplemented by more specific protocols". The Working Group's final result, the Vienna Convention, was thus, by definition, general in nature and required subsequent agreements such as the Montreal Protocol to give it specific application.

67. Vienna Convention for the Protection of the Ozone Layer, opened for signature Mar. 22, 1985. UNEP/IG.83/51 Rev. 1 (1985) reprinted in 26 I.L.M. 1516 (1987) [hereinafter Vienna Convention] (ratified by Canada on June 4,1986 ). 
As a 'framework convention', the purpose of the Vienna Convention is to create a framework by which signatories may negotiate methods of dealing with the problem of ozone layer depletion. ${ }^{68}$ The Vienna Convention is necessarily general in language. ${ }^{69}$ Yet even the general articles of this Vienna Convention were the product of vigorous, contentious negotiation between the "Toronto Group", a group of nations, including Canada, which favoured at least an $80 \%$ reduction in CFC use over a six year period, and the EEC, which favoured less stringent reduction measures. ${ }^{70}$ Again, an inhibiting factor to uniformity on the subject was the general scientific uncertainty as to the acuteness of the ozone layer dilemma. Notwithstanding this, the Vienna Convention was signed originally by twenty-one delegations, including Canada and the signing parties agreed to the implementation of a working group to draft a protocol to the Vienna Convention specifically dealing with the regulation of CFC use. ${ }^{71}$

Certain scholars have chastised the Vienna Convention for being overly vague and general in nature, concluding that it is therefore ineffective because of its failure to effect a solution on the problem of ozone layer depletion. ${ }^{72}$ Such criticism is undue, and stems from a misunderstanding of the nature of the Vienna Convention itself. As a "framework Convention" the purpose of the Vienna document was not to solve the problems of the ozone layer in itself, but rather to have signing parties agree on a framework of negotiations whereby subsequent protocols could specifically address proposed solutions to ozone layer depletion. Its success is evidenced by the September 16, 1987 signing of the first protocol to the Vienna Convention - the Montreal Protocol on Substances that Deplete the Ozone Layer.

\section{THE MONTREAL PROTOCOL}

Shortly after the signing of the Vienna Convention in late March 1985, the possibility of reaching a global consensus on procedures for protecting the ozone layer from further depletion looked promising. The Convention represented and international anticipatory agreement on ozone layer depletion. It enunciated general guidelines and international obligations relating to activities which "modify or are likely to modify the ozone layer", ${ }^{73}$ called for international co-operation in scientific research into the ozone layer problem, ${ }^{74}$ and provided the mechanism by which subsequent protocols could deal with specific

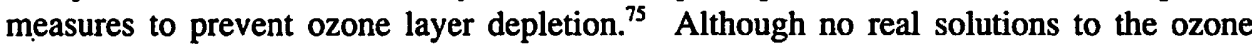
layer problem had been effected, it had accomplished its purpose, which was to implement

68. See supra, note 65 .

69. See Vienna Convention, supra, not 67, Article 2(1) which reads: "The Parties shall take appropriate measures...to protect human health and the environment against adverse effects resulting or likely to result from human activities which modify or are likely to modify the ozone layer." The idea of the Convention was that these 'appropriate measures' were to be determined in subsequent Protocols. See Sand, supra, note 59 at 41 .

See Vienna Convention, supra, note 67 at Resolution 2: "On a Protocol Concerning Chlorofluorocarbons".

See especially Blegen, supra, note 10 at 424 .

Vienna Convention, supra, note 67, Article 2.

Ibid. Articles 3-5.

Ibid. Articles 6-7. 
the means by which solutions could be obtained and agreed to internationally. Thus it appeared that timely solutions were forthcoming. However, in May of that year, British scientists reported to the world a startling discovery that had been previously unknown or unsuspected, the development of a large 'hole' in the ozone layer over Antarctica. ${ }^{76}$ This disclosure reinforced the urgency attendant upon the problem of ozone layer depletion and caused negotiations on the first protocol to the Vienna Convention to begin in earnest. The Montreal Protocol represents the culmination of those negotiations. The following is an overview of the Protocol's provisions, assessing and evaluating both its strengths and weaknesses in realizing the desired goal of prevention of further desecration of the ozone layer by CFCs and halons.

\section{A. AN OVERVIEW OF THE MONTREAL PROTOCOL}

Due to the nature of ozone layer depletion, and the fact that continuing scientific investigation is revealing more clues that lead to a better understanding of the cause and effect of the problem, the underlying characteristic of the Montreal Protocol is flexibility. It was drafted with a view to continual assessment, review, and amendment of its terms to keep it attuned to current scientific knowledge.

The central object of the Protocol is to curb the production and consumption by party states of ozone-destroying substances. These 'controlled substances' are defined in Article 1 as "a substance listed in Annex A to this Protocol, whether existing alone or in a mixture."77 Annex A presently contains only eight substances divided into two Groups. ${ }^{78}$ Based on assessments made and current scientific knowledge party states can amend the Annex to add or subtract 'controlled' compounds to the terms of the Protocol with the affirmation of a two-thirds majority of party states present and voting. ${ }^{79}$

The Protocol attempts to meet its central objective in two ways. First, it places direct controls on the "calculated levels"80 of production ${ }^{81}$ and consumption ${ }^{82}$ of controlled

Stolarski, "The Antarctic Ozone Hole" (1988) 258 Scientific American at 30. The infamous ozone 'hole' is not a complete hole properly so called, but rather a substantial thinning of the ozone layer by up to 50\%. The hole appears over the South Pole in September when the sun returns to the region after the long Antarctic night. It disappears by late October. Evidence suggests the hole is expanding in terms of size, percentage loss of ozone, and length of duration every year. More recent evidence indicates that substantial ozone loss is occurring in regions surrounding the ozone hole. See also "Ozone losses Baffle Researchers" Edmonton Journal (16 November 1989) B-23.

77. The Montreal Protocol, supra, note 4, Article 1(4).

78. Ibid. Annex A. Group I contains the 5 CFCs (CFC-11, CFC-12, CFC-113, CFC-114, and CFC-115) considered to be most damaging to the ozone layer. Group II lists three halon compounds which have a high ozone depleting potential (halon-1211, halon-1301, and halon-2402).

79. Ibid. Article 2(10).

so. "Calculated levels" of production, imports, exports, and consumption are arrived at through the formulae found in Article 3. See ibid. Article 1(7), 3.

s. "Production" is defined as the amount of controlled substances produced less the amount destroyed by "approved" technologies. "Approved" technologies are to be determined by the party states. See ibid. Article 1(5).

82. "Consumption" is the sum of production and imports less exports of controlled substances. See ibid. Article 1(6). 
substances by party states through the implementation of several restrictive measures set out in Article 2 of the Protocol. Second, it attempts to indirectly limit the production of controlled substances by non-party states through the imposition of trade restrictions on the importation of controlled substances by party states from non-parties. ${ }^{83}$

\section{Control Measures ${ }^{84}$}

Direct control measures on calculated levels of production and consumption of controlled substances are enunciated in Article 2. The Protocol does not attempt to limit each controlled substance individually, but rather, calculations are made for each Group in Annex A. The control measures are based on the party state's calculated levels of production and consumption in 1986. One exception to this is Article 2(6), which was placed in the agreement to entice the Soviet Union to sign, and allows developed nations which had begun construction on, or contracted for, production facilities prior to September 16, 1987, to add the production of all facilities completed before December 31, 1990 to their 1986 levels. ${ }^{85}$ A proviso to this exception is that the additional production must not raise the party state's calculated level of consumption above $0.5 \mathrm{~kg}$ per capita. ${ }^{86}$ Article 3 details the methods for determining a party state's calculated levels of production, import, export and consumption. A party's calculated level of production of a Group of substances for any given year is arrived at by multiplying the production (less amount destroyed) ${ }^{87}$ of each individual substance within that Group by its ozone depleting potential. ${ }^{88}$ The sum of all the resulting figures represents the calculated level of production for that Group. ${ }^{89}$ The same procedure is to be followed in calculating the levels of imports and exports for each Group. ${ }^{90}$ The calculated level of consumption is derived by adding the calculated levels of production and imports and subtracting the calculated level of exports. After 1992, exports of controlled substances to non-parties will not be included in this formula. ${ }^{91}$

See generally, ibid. Article 4.

See generally, ibid. Articles 2 and 3.

The Soviet Union insisted on this exception in order to allow it to continue with the construction of CFC-producing plants provided for in its current five year plan. The enticement was successful as the Soviet Union signed the Protocol on December 29, 1987 and ratified it on November 10, 1988. See ibid. Article 2(6).

Ibid. This is a fairly weak-kneed provision when one considers that only the United States and the EEC currently consume controlled substances at a per capita rate of higher than $0.5 \mathrm{~kg}$. In 1986, the Soviet Union consumed only $0.3 \mathrm{~kg}$. per capita of controlled substances, thus Article 2(6) will allow it to increase its 1986 per capita use by $40 \%$. See also Tripp, supra, note 22 at 744 . See supra, note 79.

The ozone depleting potential figures for each controlled substance are listed in Annex A and represent an estimation of the potential threat each controlled substance poses to the ozone layer. The higher the number, the more deleterious the substance is to the ozone layer. 
Article 2 anticipates a three step process in the control and reduction of Group I substances. Beginning on July $1,1989,{ }^{92}$ party states are required to ensure that annual calculated levels of production and consumption of substances in Group I do not exceed 1986 levels. ${ }^{93}$ Beginning on July 1, 1993, the party states must reduce the calculated levels of production and consumption by $20 \%$ over 1986 levels. ${ }^{94}$ Finally, commencing on July 1,1998 , party states are to make a further reduction to their calculated levels of production and consumption of 30\%, decreasing total CFC use by $50 \%$ of calculated 1986 levels. ${ }^{95}$ This scheme was implemented with a view to halving CFC production and consumption by the turn of the century.

Two important exceptions exist which will allow parties to increase their calculated levels of production ${ }^{96}$ above prescribed levels throughout the three stage process. The first exception allow party states to increase their calculated levels of production in order to satisfy the basic domestic CFC needs of underdeveloped countries (UDCs) ${ }^{97}$ which are parties to the Protocol. This was done to discourage UDCs from building their own CFC-producing plants. Developed countries may increase production in their plants for the purpose of providing CFCs for UDC use. The second exception pertains to 'industrial rationalization ${ }^{98}$ between party states. These exceptions allow for an increase of $10 \%, 10 \%$, and $15 \%$ respectively over prescribed levels of production in the three stages. ${ }^{99}$ Article 2(4), which describes the implementation of the third stage of Group I control and reduction, concludes with the rather superfluous provision that it may be subject to revision by a two-thirds majority of party members representing two-thirds of total party CFC use. This is unnecessary because of Article 6 which anticipates regular assessment and review of all Article 2 provisions.

As far as Group II substances are concerned, Article 2 imposes only a freeze on their calculated levels of production and consumption at 1986 levels commencing January 1, 1992. ${ }^{100}$ The same two exceptions exist for halon production as previously described

92. Article 2(1) of the Protocol requires this stage to begin on the first day of the seventh month following the Protocol's entry into force. Since the Protocol entered into force on January 1, 1989, the operation of this provision commenced on July 1 of that year.

93. Ibid. Article 2(1).

9. Ibid. Article 2(3).

95. Ibid. Article 2(4).

9. No exceptions exist for consumption levels. Party states may only increase production levels above the stated amounts for prescribed purposes.

97. "Developing countries" are given unique concessions in Article 5. See infra, note 107 and accompanying text.

98. 'Industrial rationalization' is a term of art which means the transfer of all or a portion of the calculated level of production of one party to another, for the purpose of achieving economic efficiencies or responding to anticipated shortfalls in supply as a result of plant closures, ibid. Article 1(8). Ibid. Article 2(5) describes how and by whom industrial rationalization is to be used. Just how workable this rather ambiguous term will be remains to be seen.

99. Ibid. The exceptions are repeated almost verbatim in Article 2(1),(3),(4).

100. See ibid. Article 2(2). The section states that the implementation of this provision will commence on the first day of the 37th month following the Protocol's entry into force. As the Protocol became effective January 1, 1989, this date will be January 1, 1992. 
for CFC production. If these exceptions apply, parties may increase their annual production of halons by $10 \%$ over 1986 calculated levels.

\section{Trade Restrictions and non-parties}

The second main feature of the Protocol is the trade restrictions listed in Article 4. These restrictions attempt to serve two ends. First, by reducing the potential economic advantage for non-parties, they encourage maximum participation in the Protocol. Second, by imposing stringent import and export prohibitions by party states of controlled substances from non-parties, they seek to indirectly curb the production of CFCs in non-party nations.

The first trade restriction requires party states to completely ban the import of controlled substances in their raw form from non-party states by January 1, 1990. ${ }^{101}$ Article 4(2) prohibits the exportation of controlled substances by UDCs to non-party states after 1992.

Apart from these explicit prohibitions on trade in controlled substances between party and non-party states, the Protocol contains other, less tenable provisions for the future imposition of further trade restrictions. Within three years of January 1, 1990, the parties are required to cooperate in drafting an Annex listing products containing controlled substances. This list would, foreseeably, contain such items as refrigerators and air conditioners. ${ }^{102}$ Within one year after the implementation of the Annex parties not formally objecting to the list are required to prohibit the import of listed products from non-party States. ${ }^{103}$ Furthermore, sometime before January 1, 1994, the parties are to determine the feasibility of prohibiting or restricting the importation of products produced with, but not containing, controlled substances from non-party states. ${ }^{104}$ If it is determined to be feasible, the parties are to outline in an Annex a list of these products, and one year after the Annex becomes effective, parties not objecting to it are bound to ban or restrict the import of products listed in the Annex from non-parties. Article 4(8) contains an important provision which exempts non-party states which are determined by a meeting of the Parties to be in full compliance with Protocol provisions from the trade restrictions contained in Article 4(1), (3), and (4).

Parties are exhorted to discourage the export to non-party states of technology used in the production and utilization of controlled substances. ${ }^{105}$ They are also required to refrain from providing financial aid to non-party states for the export of products, equipment, plants or technology that would assist in the production of controlled substances. ${ }^{106}$

\footnotetext{
101. Ibid. Article 4(1).

102. CFC-11, CFC-12 and CFC-114 are used as coolants in refrigerators and air conditioners.

103. Montreal Protocol, supra, note 4, Article 4(3).

104. Ibid. Article 4(4). Article 4(4) requires this to be determined within five years of the Protocol's entry into force.

105. Ibid. Article 4(5).

106. Ibid. Article 4(6).
} 


\section{Developing Countries}

Article 5 describes the privileged status of "developing countries" in this Protocol. "Developing countries" are countries which have an annual calculated level of consumption of controlled substances that is less than $0.3 \mathrm{~kg}$ per capita. They are permitted to delay compliance with control by ten years for the purpose of meeting domestic needs only. In order to take advantage of this provision, UDCs must not exceed an annual calculated level of consumption of $0.3 \mathrm{~kg}$ per capita in the ten year period. Instead of 1986 levels, these parties will use as their baseline level the lower of either the average of their annual calculated levels of consumption between 1995 and 1997 or a calculated level of consumption pegged at $0.3 \mathrm{~kg}$ per capita when they commence compliance with the control measures. ${ }^{107}$ This provision was put in place to provide an incentive for UDCs to sign the Protocol, thereby furthering the goal of maximum participation. It will effectively allow UDCs which place a high priority on the production of domestic goods, many of which are produced with or consume controlled substances, to sign the Protocol without retarding their own economic development, because they can continue to increase their use of controlled substances for a decade. 


\section{Other Provisions}

Much of the remainder of the Protocol deals with procedural and definitional matters. These include reporting of data to be used by parties for the purpose of Article 2 measures, ${ }^{108}$ co-ordination and co-operation by parties in research and development of safe substitutes, ${ }^{109}$ technical assistance for UDC parties, ${ }^{110}$ procedure at party meetings, ${ }^{111}$ duties and functions of the Secretariat, ${ }^{112}$ and financial provisions. ${ }^{113}$ Article 6 sets up a schedule for review and re-assessment of control measures on the basis of current information, beginning in 1990 and repeating every four years thereafter. Article 8 requires the parties to determine the definition and treatment of non-compliance of Protocol provisions.

Article 16 sets the entry into force of the Protocol at January 1,1989, provided that at least eleven instruments of ratification from parties representing two-thirds of the consumption of controlled substances are entered at that time. Since this requirement was fulfilled the Protocol has been in force. Article 17 stipulates that parties joining the Protocol subsequent to its coming into force must meet the control measures that currently apply when they become a participant. ${ }^{14}$ Article 19 details the withdrawal procedure. No party may effectively withdraw from the Protocol obligations for five years after assuming obligations specified in Article 2.

\section{B. CRITICAL ANALYSIS OF THE MONTREAL PROTOCOL}

The Montreal Protocol has been rightly praised as a landmark agreement in the area of international environmental law, for it represents the first multi-lateral agreement to restrict the use of substances in order to prevent future environmental woes rather than cure existing ones. ${ }^{115}$ However, as Dr. Mostafa Tolba, Executive Director of UNEP cautioned, the Protocol "is only as good as the parties are willing to make it."116 Indeed, none of the measures present in the Protocol are static, all are subject to subsequent review and amendment in light of further scientific understanding into the nature of the problem. Ironically, the Protocol's flexibility, which represents its greatest strength, is also its direst weakness, for it depends upon continued global cooperation and

Ibid. Article 13.

Thus, if a state that did not qualify under Article 5 as a developing country were to ratify the Protocol in 1995 it would immediately have to reduce its CFC calculated levels of production and consumption by $20 \%$ over its 1986 levels to place it in the same position as all other party states. This praise is becoming progressively less exultant as we come to understand just how far advanced ozone layer depletion really is, and how much former projections vastly underestimated the rapidity with which CFCs work their destruction. It is becoming apparent that ozone layer depletion is not only a future danger, it is a current one. See especially supra, note 76.

Ibid. Article 7.

Isrealson, "Holes in the Ozone Accord" World Press Review (November, 1987) 54. 
reasonableness for its success. The following is an evaluation of the strengths and weaknesses of the Protocol.

\section{Strengths}

The Protocol's flexibility is an invaluable attribute of its potential success in effectively curbing the use of ozone layer destroying substances. ${ }^{17}$ This is especially important in light of recent scientific developments which suggest that the control measures in place are conservative, and that more drastic cuts in CFC use are required to effectively prevent further degradation of the ozone layer. ${ }^{118}$ Without this element of flexibility, the Protocol would be rendered ineffective almost before its implementation. ${ }^{119}$ Through Article 6, parties are required to assess and review the Protocol's control measures every four years, and they may do so even more frequently through the 'extraordinary meetings ' provision contained in Article 11(2).

A further strength of the Protocol is that the control measures and trade restrictions imposed therein will provide economic incentives to industry to develop and introduce economical, environmentally safe substitutes for controlled substances. The provisions for restrictions and reduction will result in a shrinking market for controlled substances themselves, while demand will be high for safe substitutes. ${ }^{120}$ The trade restrictions should also encourage states ${ }^{121}$ to join the Protocol since they effectively negate the economic incentive for non-parties to expand production of CFC products for export to party states. ${ }^{122}$

Finally, the Protocol must be praised for being a unique, precedent-setting agreement in the area of international environmental law. It represents an anticipatory, co-operative response to an urgent environmental crisis by states from disparate social, political and economic backgrounds in which each individual state subjugated its economic self-interest in the face of pressing environmental concerns.

\section{Weaknesses}

117.

118.

See especially Article 6 of the Montreal Protocol, supra, note 4.

See infra, note 125-127 and accompanying text.

By the Protocol's coming into force on January 1, 1989 new scientific data indicated the depletion problem was far more extensive that previously suspected, and that immediate, drastic reductions of CFC use were necessary to prevent further depletion. See supra, notes 31-37 and accompanying text; especially Shabecoff article (note 33). See also infra, notes 125-127 and accompanying text.

Industry has responded to the challenge of finding safe substitutes for CFC use. Many substitutes already exist for aerosol and refrigeration applications. DuPont, a multi-national corporation, which is the world's largest CFC producer, announced it has developed and patented a CFC substitute for use in air conditioners and refrigerators. The substitute will be marketed commercially in 1993. See Weisskopf, M., "DuPont Creates Replacement for Ozone-Depleting Chemicals", Washington Post, 31 January 1989 A6.

\footnotetext{
Especially developed nations which are net exporters of CFCs.
}

This of course depends on later amendments which are anticipated to outline sanctions against party states for non-compliance with Protocol provisions, and to limit the rather vague 'opting out provisions contained in Articles 4(3) and (4) of the Protocol. 
A critical examination into the Protocol's provisions reveals a number of glaring omissions which weaken the enforceability, and therefore the effectiveness, of the Protocol itself. Most important of these omissions is that the Protocol in its present form, does not provide for verification of compliance with control and trade restriction measures, nor for sanctions against parties which fail to comply with those measures. ${ }^{123}$ Also, the Protocol provides no scheme for a reduction in the production and consumption of halons, which have enormous ozone destroying potential. ${ }^{124}$

However, the vast majority of the Protocol's weaknesses come not in what it omits to say, but in what it says. These inadequacies can be broadly stated as follows: a) a failure to establish adequate schemes of ozone-depleting substances; and b) inclusion of unnecessarily broad concessions which reduce the effectiveness of the agreement in preventing further damage to the ozone layer.

\section{(a) Inadequate Reduction Schemes}

The reduction scheme at present contemplates that by 1999 the use of controlled substances by party states will be reduced to $50 \%$ of their 1986 levels. ${ }^{125}$ This amount, impressive as it may look at first glance, is inadequate to achieve the Protocol's stated goal of preservation of the ozone layer. The reductions are too small and come too slowly. Immediate reduction is required because of the high levels and long life of CFCs currently in the troposphere. ${ }^{126}$ Due to the fact that CFCs already released will continue to damage the ozone layer for the next one hundred years, the United States Environment Protection Agency estimated that an immediate $85 \%$ reduction in CFC use would merely maintain current CFC levels in the atmosphere. ${ }^{127}$ In light of this, the proposed $50 \%$ reduction over 10 years contained in the Montreal Protocol looks to be a paltry sum indeed. The Protocol's planned reduction of CFC use by $50 \%$ over 10 years, far from effecting a decrease in atmospheric CFC levels and protecting the ozone layer as intended,

Article 8 only sets out that the matter of non-compliance is to be dealt with at the first meeting of the parties. Pursuant to Article 8, a meeting of legal experts was convened during the first meeting of the parties to the Protocol in Helsinki, Finland from May 2-5, 1989. That meeting outlined the issues and set up the Ad Hoc Working Group of Legal Experts on Non-Compliance with the Montreal Protocol, which first met in Geneva, Switzerland on July 11-14, 1989. There was no Canadian representative present at the July meeting. This working group decided to establish a committee on non-compliance which would review data to determine whether a party was in breach of its Protocol obligations. The committee would be comprised of five members elected by the parties, and would not exercise a judicial function, rather final decisions on non-compliance, and determination of what sanctions would be imposed on offending parties would be dealt with at a party meeting. This leaves open the question of what measures will be taken against parties found to be in breach of the Protocol provisions. See "Non-Compliance with Ozone Agreement," (1989) 19 Environmental Policy and Law 147.

Halon-1301, one of the three controlled substances listed in Group II of Annex A to the Protocol, has an ozone depleting potential which is ten times greater than the strongest CFC. Article 2(2) of the Protocol, dealing with halons, freezed their production and consumption at 1986 levels. The $20 \%$ and $30 \%$ reductions contemplated in Articles 2(3) and (4) respectively add up to a $50 \%$ total reduction of CFC production and consumption from 1986 levels.

See supra, note 30 and accompanying text.

See Davidson, C.B., "The Montreal Protocol: The First Step Toward Protecting the Global Ozone Layer" 20 New York University Joumal of International Law and Politics 793 at 800. 
will not even prevent further increases in CFC levels and the destruction of ozone attendant upon it. Thus, damage to the ozone layer is likely to increase in the next 10 years in spite of the Montreal Protocol. This is potentially hazardous for the polar nations, such as Canada, because further expansion of the Arctic and Antarctic 'holes' can be expected.

\section{(b) Unnecessarily Broad Concessions}

The situation is exacerbated, and the weakness of the Protocol made more apparent when one considers that the $50 \%$ reduction, inadequate as it is to prevent continuing damage, represents only the 'best case' scenario under the Protocol. In order to attain its subsidiary goal of maximum participation, the Protocol makes some key concessions to potential signatories which will likely whittle away from the Protocol's already insufficient $50 \%$ reduction rate. ${ }^{128}$ The largest concession was that given to 'developing nations', and is contained in Article 5 of the Protocol. Under this provision, UDCs with a current consumption rate of less than $0.3 \mathrm{~kg}$ per capita of controlled substances are allowed to waive compliance with the terms of the Protocol for ten years. If all UDCs take advantage of this concession, and increase their annual CFC consumption rate to $0.3 \mathrm{~kg}$ per capita ${ }^{129}$ over the 10 year period, global production and consumption of CFCs will be 50\% greater in 1999 than in 1986, even if all developed nations strictly adhere to the control measures and reduce their CFC production and use by $50 \% .{ }^{130}$ Even this huge concession was insufficient to convince China and India, two developing countries with huge populations, to sign the Protocol.

Another concession that undermines the already insufficient control measures in the Protocol is the concession which allows parties which are in the process of building CFC production plants to add the production from those plants to their 1986 baseline level. ${ }^{131}$ This concession was given at the insistence of the Soviet Union in order to allow them to continue with construction plans under their current five year plan. ${ }^{132}$ The Protocol thus allows the Soviet Union to increase its baseline rates of production and consumption up to $0.5 \mathrm{~kg}$ per capita ${ }^{133}$ through the operation of these new facilities, the only proviso being that the facilities must be constructed by December $31,1990 .{ }^{134}$

Since these concessions were placed in the Protocol to induce certain nations to sign it, and many of those nations did indeed sign it, there is no reason to assume they will not be acting upon the concession given to them.

129. The maximum allowable under Article 5(1). Supra, note 4.

130. Over $75 \%$ of the world's population resides in what Article 5 classifies as 'developing countries', and qualify for this concession. Thus, the scheme under the Protocol contemplates $75 \%$ of the global population increasing their CFC consumption rate by as much as $500 \%$ (Egypt, a signatory to the Protocol had a 1986 consumption rate of $0.06 \mathrm{~kg}$ ) while $25 \%$ of the world's population engages in a 50\% reduction. See also Tripp, supra, note 22 at $741,744$.

131. Montreal Protocol, supra, note 4, Article 2(6).

132. See Weisskopf, M., "Nations Sign Agreement to Guard Ozone Layer", Washington Post (12 September 1987) A3.

133. Average global consumption is $0.2 \mathrm{~kg}$ per capita, hence, the Soviet Union will be allowed to increase its production under the Protocol to a rate of $150 \%$ higher than the global production rate. See Tripp, supra, note 22 at 741.

134. Montreal Protocol, supra, note 4, Article 2(6). 
A third concession given in the Protocol with an aim to ensuring maximum participation is Article 2(8), which allows members of 'regional economic integration organizations $^{135}$ to agree to jointly fulfil the control measures. ${ }^{136}$ This concession was given to encourage individual members of the EEC to sign the Protocol. Through it, the member states may choose to have one combined consumption and production rate. This will allow Great Britain and France, who most vigorously opposed high reduction rates, ${ }^{137}$ to produce and consume CFCs at a higher rate than provided for in the Protocol, as long as other EEC members produce and consume CFCs at a lower rate than required. $^{138}$

These three concessions, given with an aim to garnering maximum participation, are not the only weaknesses inherent in the Protocol's provisions. Other mechanisms exist whereby member nations may skirt around their Protocol obligations, and thereby undercut further the already minimal effectiveness of the reduction measures. While control of consumption is binding on all parties, each of the control measures described in Article 2 allows nations to increase their production of controlled substances by 10 $15 \% .^{139}$ Production obligations may be breached in this manner for two purposes, 'industrial rationalization' and to aid 'developing countries'. The reason for including the former is to achieve "economic efficiencies or (respond) to anticipated shortfalls in supply as a result of plant closures." ${ }^{140}$ The purpose of the latter is to dissuade UDCs from spending money on building their own CFC production facilities by ensuring that their heightened demand for CFCs may be met by countries with existing production facilities. ${ }^{141}$ The extent of this weakness depends upon subsequent interpretation of ambiguous terms such as 'economic efficiencies', and 'shortfalls in supply', ${ }^{142}$ and

Article 2(8), which allows countries of a 'regional economic integration organization' to join together in fulfilling the control measures of Article 2, refers to Article 1(6) of the Vienna Convention for an explanation of this term. The Vienna Convention defines a 'regional economic integration organization' as an "organization constituted by sovereign states of a given region which has competence in respect of matters governed by this convention or its protocols and has been duly authorized in accordance with its internal proceeding to sign, accept, approve, or accede, to the instruments concerned". See Vienna Convention, supra, note 67, at Article 1(6).

136. This is an interesting development in the field of public international law. Hitherto, only sovereign states and certain international organizations have been recognized as full and proper subjects of international law. The Vienna Convention with its adherent Protocol seems to confer 'subject' status upon economic organizations like the EEC. Whether this concept will be adopted in other areas of public international law remains to be seen.

137. See also Davidson, supra, note 127 at 813.

138. Ibid. West Germany will likely reduce its CFC production and consumption at a quicker pace than called for in the Protocol. Without this concession, Great Britain and France would have to adhere to their own individual calculated levels and could not benefit from West Germany's action. Article 2(8) effectively allows them to produce at a higher rate so long as the EEC as a whole adheres to its conglomerate calculated levels of production and consumption.

139. See Protocol, supra, note 4. Articles 2(1-3) allow a 10\% increase in production, while Article 2(4) provides for a $15 \%$ rise over 1986 calculated levels of production.

140. Ibid, Article 1(8).

141. See supra, note 97 and accompanying text.

142. If given a broad interpretation, these terms could be used to excuse heightened production of CFCs for a myriad of purposes. 
whether or not UDCs will decide to build their own production plants notwithstanding. ${ }^{143}$

One purpose of the trade restrictions contained in Article 4 is to put economic pressure on non-parties to join the Protocol by removing the economic incentives for abstaining. ${ }^{144}$ This purpose is undercut, however, through Articles 4(3) and (4) which allow any or all parties to object to the list of products created under those sections. Since objecting parties neither are required to give reasons for their objections, nor face penalties for objecting, these innocuous-sounding phrases essentially provide opportunity for party states to import CFC products in spite of the Protocol provisions, thereby defeating entirely the purpose of these provisions. ${ }^{145}$

Tragically, many of these concessions, which further debilitate the already weak measures and restrictions contained in the Protocol, are unnecessary because of the prevalence of many safe substitutes readily available, and the prospect that others will be developed in the near future. ${ }^{146}$ Much of the CFC use by EEC countries is unnecessary. ${ }^{147}$ As well, rather than providing means by which UDCs may increase CFC use through various concessions, the Protocol should be encouraging and facilitating the use and development by UDCs of safe substitutes.

In spite of what may be said of the insufficiency of the Protocol's measures, ${ }^{148}$ it is a significant achievement that the parties agreed to substantial restrictions of their production and consumption of CFCs and halons solely for environmental reasons. ${ }^{149}$ In the past, environmental concerns always took a subservient position to economic advancement, and previous international agreements on environmental protection where

143. This contingency may be the proverbial 'double-edged sword that cuts both ways. If UDCs opt to build their own facilities, the result would be less use of this provision by developed countries to increase CFC production. On the other hand, that would mean more production facilities for a substance the production and use of which the globe is ostensibly trying to reduce.

144. Demand for CFCs, or substitutes, will rise substantially, even during the 'freeze' stage of the Protocol. Thus, a country, particularly one which is a net exporter of CFCs, would have an incentive to not join the Protocol and export higher priced controlled substances to CFC-starved party members were it not for the trade restrictions.

145. Article 10(b) of the Vienna Convention, which governs this procedure, requires simply that objecting parties notify the Depository in writing of their intention to object within six months of the adoption of the Annex. No requirements as to content of the notice (i.e. reasons, etc.) exist. See Vienna Convention, supra, note 67, Article 10, especially 10(6).

146. Safe, economically efficient substitutes already exist for CFC applications in aerosol cans, insulation. cleaning solvents, and foamed plastic. Recovering CFCs from old refrigerators and air conditioners could reduce the demand for new CFCs as coolants substantially. See also Davidson, supra, note 127 at 814.

147. Use of CFCs in aerosol spray cans is still common among EEC member states.

148. See supra, notes 123-147 and accompanying text.

149. CFCs are big business and have a variety of industrial and commercial uses. See supra, notes 19-23 and accompanying text. That nations agreed to selflessly discard this economical gold mine is indeed laudable. 
they interfered with economic interests, were rarely settled. ${ }^{150}$ It is hoped that the Protocol will illustrate the success that can be achieved through compromise and cooperation.

\section{PROPOSALS FOR CHANGE}

In order to achieve that success, certain amendments need to be made to overcome the inadequacies inherent in the Protocol. Happily, the Protocol is a document that was drafted in a manner that makes it amenable to change. ${ }^{151}$ The intangible element in the Protocol's ability to improve itself is that it is dependent upon continued co-operation by the parties, ${ }^{152}$ continued subversion of individual nations' self-serving interests to a common global good, a rare event in the history of public international law.

Most importantly, the weak control measures need prompt action to strengthen them and to bring them up to date with current scientific data on ozone layer depletion. To this end, an amendment should be made calling for an immediate $85 \%$ reduction in CFC use, ${ }^{153}$ followed by a total ban within five years. ${ }^{154}$ Halon use should be restricted in a similar fashion due to its high ozone depleting potential..$^{155}$

An amendment should also address the numerous omissions and ambiguities in the Protocol, and seek to clarify and strengthen its provisions. In particular, Article 7, which deals with data reporting by party states, should be revised, and penalties imposed on parties who are guilty of mendacious reporting. The non-compliance procedures and sanctions need to be established quickly and coherently with stringent, effective means and measures for penalizing non-compliance. ${ }^{156}$ One possible sanction could be that non-complying states be made subject to even stricter reduction measures, with economic sanctions to be imposed should there be further failure to comply. Furthermore, a strict

A notable example of this is the continuing difficulties encountered by American and Canadian negotiators in concluding an agreement on the acid rain problem. See generally, Brunnée, supra, note 64 at $190-210$.

131. $\quad$ See generally Montreal Protocol, supra, note 4, Article 6.

152. Ibid. Article 2(10)(b) requires a two-thirds majority of party members present and voting to amend the control measures contained therein.

133. This is the amount required to maintain current atmospheric CFC levels and prevent further damage to the ozone layer. See supra, note 127 and accompanying text. Such a reduction is not an unrealistic expectation. Indeed, member states of the EEC, previously among those most opposed to CFC reduction, recently announced their resolve to cut production of CFCs by $85 \%$ as soon as possible, and to eliminate CFC use and production altogether by the turn of the century. See Whitney, C.R., "12 European Nations to Ban Chemicals that Harm Ozone" New York Times (3 March 1989) Al. At a March 5, 1989 worldwide conference on the ozone layer, Great Britain proposed a global $85 \%$ reduction of CFCs and halons by the end of the century. The proposal failed due to objections by UDCs such as China and India, and the Soviet Union. See also Whitney, C.R., "20 Nations Agree to Join Ozone Pact" New York Times 8 March 1989 A12, col. 1.

154. This would allow time for the substitutes currently in production to be marketed. Only through a complete ban on CFC use will the atmosphere be able to being the arduous process of flushing out current CFC levels.

iss. See Montreal Protocol, supra, note 4 at Annex A.

156. See supra, note 123 for details on what has already been done on the non-compliance issue. 
interpretation of ambiguous phrases such as 'economic efficiencies' 157 is required to prevent potential abuses of the production concessions listed in Articles 2(1) and (4). The term 'developing country' in Article 5 should be given a narrow definition to include only truly UDCs, so that countries with a hitherto low production and consumption rate of CFCs will be unable to qualify for developing country status for the sole purpose of avoiding the Prorocol provisions. Also, 'basic domestic needs' ${ }^{158}$ should be strictly construed to refer to only domestic demands of the UDC, and not needs of the UDC to strengthen its economy through exports. Although it may be unfair to do away with the Article 5 concession entirely, since that would unduly place the burden of high CFC use on developing nations, and retard their economic growth when it was largely the excess of the developed nations that caused the crisis initially, review of that provision should be undergone with a view to limiting it. At the least the focus for the 'developing nations' provision should be on facilitating their acquisition and production of safe substitutes for CFCs. It is likely, given the current rate at which substitutes are being developed and marketed, ${ }^{159}$ that a 10 year delay in compliance may be too long.

Both the import restriction on products containing or made with CFCs and the export prohibition on any controlled substance, should be implemented at the same time as the ban on imports of raw CFCs from non-parties. ${ }^{160}$ No question of feasibility should be entertained in reference to goods made with CFCs. ${ }^{161}$ It is imperative that these trade restrictions be effective in order to negate any economic benefit attendant in not joining. To this end also, the objection procedure which allows objecting parties to opt out of the trade restrictions on goods containing or made with CFCs, ${ }^{162}$ should be abolished, or at least strictly monitored. The objection procedure is really unnecessary, since trade restrictions should be just as binding on parties as are the control measures. However, at the very least, parties who object should be required to show reasonable cause for their objection. The decision on the reasonableness of a party's objection should be remanded to an elected committee made up of legal experts from member states. An appeal of the committee's decision could then be tabled at an extraordinary ${ }^{163}$ meeting of the parties to ensure justice was obtained. Also, certain penalties for objection should be imposed to ensure that parties will only object for serious reasons.

Increased economic sanctions and diplomatic pressure should be applied to nations such as China and India which remain obstinate in their refusal to sign the Protocol, and plan increases in their use of CFCs over the next decade.

157. Montreal Protocol, supra, note 4, Article 1(8).

158. Article 5 allows 'developing countries' to waive Protocol responsibilities for ten years and increase CFC production up to $0.3 \mathrm{~kg}$ per capita in order to meet 'basic domestic needs'.

139. See supra, note 146.

180. That is, January 1, 1990. See Montreal Protocol, supra, note 4, Article 4(1).

161. Ibid. Article 4(4) allows for the parties to question the feasibility of restricting trade with non-parties on goods made with CFCs.

162. Ibid. Article 4(3) and (4). See also Vienna Convention, supra, note 67, Article 10.

163. Ibid. Article 11(2) allows for extraordinary meetings of the parties to be convened within six months of a written request by a party state confirmed by the support of one third of the party states. 
Although the periodic assessment and review of the Protocol's provisions will not occur again until $1994,{ }^{164}$ these proposals could be effected within six months by the use of the extraordinary meeting procedure contemplated in Article 10(2). If implemented, these proposals will go a long way in increasing the effectiveness of the Protocol, and allow it to reach the potential inherent in it.

\section{CONCLUSION}

The problem of ozone layer depletion is unlike any other previously addressed on an international scale. Due to its nature, and the substantial harm that will accrue if it is not effectively checked, protection of the ozone layer can only be secured through international cooperation.

Presently, international environmental law on protection of the ozone layer is inadequate. The customary sources of international law in this area as expressed in the Trail Smelter, Corfu Channel, and Lake Lanoux decisions and stated in Principle 21 of the Stockholm Declaration, do not effectively deal with the ozone problem, because no causal link can be established between an offending state's emissions and an offended state's injury. The ozone layer is a global resource and needs to be preserved on a global scale. However, customary international law is not static, and new principles of custom evolve to govern new areas of international law. The concept of the "common heritage of mankind" has been developed over the past two decades and has seen application in international law on the sea bed, in outer space, and in Antarctica. This developing customary principle would fit well with the emerging field of international law on protection of the ozone layer. The ozone layer, which envelops the entire earth, is clearly a heritage common to all humans, and its protection is vital to global welfare.

It has been seen as well that the Montreal Protocol falls short of attaining its stated object. It is encouraging to note, however, that the international cooperation on this subject, which characterized the Protocol's negotiations, is continuing. The events of recent months have witnessed the EEC member states pledge their commitment to a CFC reduction scheme which is far more drastic than that required in the Protocol, and host a global conference in an attempt to encourage other states to follow suit. ${ }^{165}$ Canada too, has taken a leading role in the now world-wide fight against CFC use. On February 20,1989 , the federal government announced its intention to "ban most ozone-destroying chemicals during the next ten years." 166 In taking this bold unilateral action, the Canadian government called on other states to do likewise.

Although these unilateral acts by the EEC and Canada are a positive indication that a growing number of states are willing to adequately address the ozone layer problem, a multi-lateral agreement to reduce CFCs at an effective rate remains of critical importance. The Montreal Protocol, although a significant first step towards rectifying the ozone

164

Ibid, at Article 6. Assessment and review meetings are schedule to commence in 1990 and repeat every four years thereafter.

165. See supra, note 153.

166. "Canada to Ban Ozone-Harming Chemicals", San Francisco Chronicle (21 February 1989) 2. 
dilemma, should be either upgraded to incorporate realistic reduction schemes, or be replaced by a stronger document. Either way, recent scientific data has shown that time is of the essence in settling a potent scheme for CFC reduction. ${ }^{167}$ International law on protection of the ozone layer is insufficient as it stands now. The Protocol has been outflanked by the latest scientific discoveries. Propitiously, the Protocol's provisions are flexible enough to allow for reassessment and amendment, but that remains a contingency. Presently, the Protocol's provisions, and indeed international law on this subject, are very much 'up in the air'. Unfortunately, so are the CFCs. 